\title{
Antibiotic resistant bacteria in surface waters in Slovakia
}

\author{
Andrea Štefunkováa, Klára Cverenkárováa , Monika Krahulcováa, \\ Tomáš Mackulak ${ }^{\mathrm{b}}$ Lucia Bírošováa
}

\begin{abstract}
${ }^{a}$ Department of Nutrition and Food Quality Assessment, Faculty of Chemical and Food Technology, Slovak University of Technology in Bratislava, Radlinského 9, SK-812 37 Bratislava, Slovak Republic ${ }^{b}$ Department of Environmental Engineering, Faculty of Chemical and Food Technology, Slovak University of Technology in Bratislava, Radlinského 9, SK-812 37 Bratislava, Slovak Republic andrea.stefunkova@stuba.sk
\end{abstract}

\begin{abstract}
This work deals with the occurrence of selected antibiotic resistant bacteria in Slovak surface waters. Total and antibiotic resistant coliform bacteria, enterococci and coagulase positive staphylococci were determined in 34 samples of surface water from rivers and still waters (dams, natural lakes, thermal bath) some of them used for recreational swimming. Sampling was performed during summer season 2017 (July and August). The number of total coliforms ranged from $1.74 \log \mathrm{CFU} / 10 \mathrm{~mL}$ to $3.69 \log \mathrm{CFU} / 10 \mathrm{~mL}$. Coliform bacteria were registered in each tested sample. The highest number was observed in the sample from river Hron. Majority of samples contained ampicillin and tetracycline resistant bacteria. Enterococci were determined in $70 \%$ of samples ranging from $0.78 \log \mathrm{CFU} / 10 \mathrm{~mL}$ to $3.81 \log \mathrm{CFU} / 10 \mathrm{~mL}$. The highest number of enterococci was observed in river Váh. Ampicillin and vancomycin resistance prevailed over ciprofloxacin and gentamicin resistance. Coagulase positive staphylococci were present in $91 \%$ of samples in the range of 0.70-3.03 $\log$ CFU/10 mL. Antibiotic resistant coagulase positive staphylococci were observed only in $32 \%$ of samples, predominantly from rivers. In these samples, chloramphenicol resistance predominated. In three samples of water used for recreational purposes, the limit value for enterococci and E. coli according to Slovak legislation (Decree no. 308/2012 Coll.) for the quality of water in natural swimming pools during bathing season was exceeded.
\end{abstract}

Key words: antibiotic resistance, coliforms, enterococci, surface water

\section{Introduction}

Antibiotic resistance represents a huge problem, already killing hundreds of thousands of people around the world. Although this threat is lurking behind the current virus outbreak, it could already complicate the care of many COVID-19 patients. Emergence and spread of multidrug resistant bacteria are not connected only to healthcare institutions as these bacteria can persist in animals, humas and the environment (Aslam et al., 2018).

Many studies point out that wastewater treatment plants (WWTPs) represent a hotspot of such resistance (Berendonk et al., 2015; Ribeiro et al., 2015; Mackulak et al., 2019). Treated water contains different pharmaceuticals (including antibiotics in subinhibitory concentrations), susceptible and antibiotic resistant bacteria as well as antibiotic resistance genes. Such water gets to the recipient which can also be surface water (river, lake, etc.). Sub-inhibitory concentrations of antibiotics play an important role in bacterial communication as a regulatory compound and signalling molecules, which leads to biofilm formation or changes in the underlying bacterial metabolism. On the other hand, low antibiotic concentrations lead to the selection of antibiotic resistant population (Stiborová et al., 2018). One of the greatest concerning the presence of these drugs in the environment is the emergence and spread of antibiotic resistant bacteria and genes encoding resistance. Subinhibitory concentrations of antibiotics can also contribute to horizontal transfer of such genes located on transposons, integrons or plasmids between bacteria of the same but also of different species (Huerta et al., 2013).

Biological contamination of surface water is predominantly caused by anthropogenic activity (O'Flaherty and Cummins, 2017). This contamination includes also antibiotic resistant bacteria and antibiotic resistance genes, which present a threat to human health, especially in surface waters intended for recreational swimming. In early 1980s, coliform bacteria of genus Escherichia, Klebsiella, Citrobacter and Enterobacter isolated from surface water samples were found to posses antibiotic resistance (Niemi et al., 1983). Stange et al. (2016) studied resistance genes in coliform bacteria isolated from river Rhine in Germany demonstrating that surface water is an important reservoir of genes encoding resistance to a wide spectrum of antibiotic classes, such as sulfonamides, tetracyclines and $\beta$-lactams. The majority of bacteria originating in seawater are resistant to more than one antibiotic (Baquero et al. 2008). 
The object of our work was to monitor antibiotic resistant coliforms, enterococci and coagulase positive staphylococci prevalence in different Slovak surface waters.

\section{Material and methods}

\section{Characterization of sampling sites}

Samples of surface water were obtained from 12 rivers (Table 1), six lakes, two dams and one thermal bath (Table 2) in the Slovak Republic and one sample was taken from a lake in Austria (Lake Neusiedl) (Table 2). Altogether 24 samples from rivers were tested; however, more sampling sites on the same river were taken on different dates in some cases (samples 1 and 5; samples 13 and 23). Sampling was realized in the summer season 2017 (July-August) and the samples were collected into sterile cold tubes and transferred in a fridge box to the laboratory for microbiological assessment.

Tab. 1. Sampling sites of surface water from rivers.

\begin{tabular}{|c|c|c|c|c|c|}
\hline Sample & Sampling site & GPS & Sample & Sampling site & GPS \\
\hline 1 & Rudno stream & $\begin{array}{l}48^{\circ} 52^{\prime} 55.5 ” \mathrm{~N} \\
18^{\circ} 44^{\prime} 51.2^{\prime \prime} \mathrm{E}\end{array}$ & 14 & Danube - Devín & $\begin{array}{l}48^{\circ} 10^{\prime} 13.8^{\prime \prime} \mathrm{N} \\
16^{\circ} 58^{\prime} 56.6^{\prime \prime} \mathrm{E}\end{array}$ \\
\hline 2 & $\begin{array}{l}\text { Hron - near Kame- } \\
\text { nica nad Hronom }\end{array}$ & $\begin{array}{l}47^{\circ} 49,38.0 ” \mathrm{~N} \\
18^{\circ} 43,18.0^{\prime \prime} \mathrm{E}\end{array}$ & 21 & $\begin{array}{c}\text { Čierny Hron - Čierny } \\
\text { Balog }\end{array}$ & $\begin{array}{l}48^{\circ} 44^{\prime} 04.9^{\prime \prime} \mathrm{N} \\
19^{\circ} 41^{\prime} 16.5^{\prime \prime} \mathrm{E}\end{array}$ \\
\hline 3 & $\begin{array}{c}\text { Váh - behind WWTP } \\
\text { Trenčín }\end{array}$ & $\begin{array}{l}48^{\circ} 52^{\prime} 46.6 ” \mathrm{~N} \\
18^{\circ} 00^{\prime} 16.9 ” \mathrm{E}\end{array}$ & 22 & Hron - Kremnička & $\begin{array}{l}48^{\circ} 41^{\prime} 51.9 ” \mathrm{~N} \\
19^{\circ} 07^{\prime} 40.8 ” \mathrm{E}\end{array}$ \\
\hline 5 & Rudno stream & $\begin{array}{l}48^{\circ} 53,19.5 ” \mathrm{~N} \\
18^{\circ} 44^{\prime} 31.1 ” \mathrm{E}\end{array}$ & 23 & Nitra - Klačno & $\begin{array}{l}48^{\circ} 55^{\prime} 04.5^{\prime \prime} \mathrm{N} \\
18^{\circ} 39^{\prime} 43.4^{\prime \prime} \mathrm{E}\end{array}$ \\
\hline 6 & Nitra - Nováky & $\begin{array}{c}48^{\circ} 26^{\prime} 09.2 ” \mathrm{~N} \\
18^{\circ} 19^{\prime} 31.1 ” \mathrm{E}\end{array}$ & 24 & Bebrava - Krušovce & $\begin{array}{l}48^{\circ} 35^{\prime} 37.9 ” \mathrm{~N} \\
18^{\circ} 13^{\prime} 41.9^{\prime \prime} \mathrm{E}\end{array}$ \\
\hline 7 & $\begin{array}{c}\text { Confluence } \\
\text { of Danube and } \\
\text { Morava - Devín }\end{array}$ & $\begin{array}{l}48^{\circ} 10^{\prime} 23.1 ” \mathrm{~N} \\
16^{\circ} 58^{\prime} 36.3 ” \mathrm{E}\end{array}$ & 25 & $\begin{array}{c}\text { Bebrava - Bánovce } \\
\text { nad Bebravou }\end{array}$ & $\begin{array}{l}48^{\circ} 43^{\prime} 55.8^{\prime \prime} \mathrm{N} \\
18^{\circ} 15^{\prime} 56.0^{\prime \prime} \mathrm{E}\end{array}$ \\
\hline 8 & $\begin{array}{c}\text { Nitra - } \\
\text { Nedožery-Brezany }\end{array}$ & $\begin{array}{l}48^{\circ} 49^{\prime} 33.1 ” \mathrm{~N} \\
18^{\circ} 38^{\prime} 19.1 ” \mathrm{E}\end{array}$ & 26 & Bebrava - Šípkov & $\begin{array}{l}48^{\circ} 51^{\prime} 01.0 ” \mathrm{~N} \\
18^{\circ} 17 ’ 03.4 ” \mathrm{E}\end{array}$ \\
\hline 9 & Danube - Štúrovo & $\begin{array}{l}47^{\circ} 47^{\prime} 26.5 ” \mathrm{~N} \\
18^{\circ} 43,27.0 ” \mathrm{E}\end{array}$ & 28 & $\begin{array}{c}\text { Bočovka - Čierne } \\
\text { Klačany }\end{array}$ & $\begin{array}{l}48^{\circ} 20^{\prime} 22.4^{\prime \prime} \mathrm{N} \\
18^{\circ} 25,33.5 ” \mathrm{E}\end{array}$ \\
\hline 10 & $\begin{array}{c}\text { Morava - near the } \\
\text { confluence of Morava } \\
\text { and Thaya }\end{array}$ & $\begin{array}{l}48^{\circ} 36^{\prime} 56.9 ” \mathrm{~N} \\
16^{\circ} 56^{\prime} 22.2^{\prime \prime} \mathrm{E}\end{array}$ & 29 & Žitava - Vlkas & $\begin{array}{l}48^{\circ} 07^{\prime} 34.6 ” \mathrm{~N} \\
18^{\circ} 16^{\prime} 13.2^{\prime} \mathrm{E}\end{array}$ \\
\hline 11 & $\begin{array}{c}\text { Nitra - Nitrianske } \\
\text { Pravno }\end{array}$ & $\begin{array}{l}48^{\circ} 52^{\prime} 25.9 ” \mathrm{~N} \\
18^{\circ} 38^{\prime} 29.6 ” \mathrm{E}\end{array}$ & 30 & Leveš - Topolčianky & $\begin{array}{l}48^{\circ} 25^{\prime} 10.4^{\prime \prime} \mathrm{N} \\
18^{\circ} 24^{\prime} 45.2^{\prime} \mathrm{E}\end{array}$ \\
\hline 12 & $\begin{array}{c}\text { Myjava - near the } \\
\text { confluence of Myjava } \\
\text { and Morava }\end{array}$ & $\begin{array}{l}48^{\circ} 37^{\prime} 42.5 ” \mathrm{~N} \\
16^{\circ} 57^{\prime} 29.5 ” \mathrm{E}\end{array}$ & 31 & Nitra - Chalmová & $\begin{array}{l}48^{\circ} 39^{\prime} 43.8^{\prime \prime} \mathrm{N} \\
18^{\circ} 28^{\prime} 56.6 ” \mathrm{E}\end{array}$ \\
\hline 13 & Nitra - Klačno & $\begin{array}{l}48^{\circ} 54^{\prime} 34.9 ” \mathrm{~N} \\
18^{\circ} 39^{\prime} 24.8 ” \mathrm{E}\end{array}$ & 32 & Nitrica - Valaská Belá & $\begin{array}{l}48^{\circ} 53^{\prime} 19.7^{\prime \prime} \mathrm{N} \\
18^{\circ} 24^{\prime} 07.5 ” \mathrm{E} \\
\end{array}$ \\
\hline
\end{tabular}

Tab. 2. Sampling sites of surface water from lakes, dams and thermal bath.

\begin{tabular}{|c|c|c|c|c|c|}
\hline Sample & 4 & 15 & 16 & 17 & 18 \\
\hline Sampling site & Orava dam & Zlaté piesky lake & Vajnory lakes & Kuchajda lake & Štrkovec lake \\
\hline \multirow{2}{*}{ GPS } & $49^{\circ} 25,10.5 ” \mathrm{~N}$ & $48^{\circ} 11^{\prime} 6.6^{\prime \prime} \mathrm{N}$ & $48^{\circ} 11^{\prime} 37.4^{\prime \prime} \mathrm{N}$ & $48^{\circ} 10^{\prime} 10.8^{\prime \prime} \mathrm{N}$ & $48^{\circ} 9^{\prime} 30.8^{\prime \prime} \mathrm{N}$ \\
\hline & $19^{\circ} 30^{\prime} 22.7 ” \mathrm{E}$ & $17^{\circ} 11^{\prime} 14.9 " \mathrm{E}$ & $17^{\circ} 12,34.6 ” \mathrm{E}$ & $17^{\circ} 8,44.2 ” \mathrm{E}$ & $17^{\circ} 8,55.0 " \mathrm{E}$ \\
\hline Sample & 19 & 20 & 27 & 33 & 34 \\
\hline Sampling site & $\begin{array}{c}\text { Vel'ký Draždiak } \\
\text { lake }\end{array}$ & Lake Neusiedl & Nitrianske Rudno & Lake Virt & $\begin{array}{c}\text { Thermal bath - } \\
\text { Patince }\end{array}$ \\
\hline \multirow{2}{*}{ GPS } & $48^{\circ} 06^{\prime} 21.8^{\prime} \mathrm{N}$ & $47^{\circ} 55^{\prime} 42.9 ” \mathrm{~N}$ & $48^{\circ} 48^{\prime} 52.4^{\prime \prime} \mathrm{N}$ & $47^{\circ} 44^{\prime} 56.3 ” \mathrm{~N}$ & $47^{\circ} 44^{\prime} 50.0^{\prime \prime} \mathrm{N}$ \\
\hline & $17^{\circ} 06,27.1 ” \mathrm{E}$ & $16^{\circ} 50^{\prime} 4.2^{\prime \prime} \mathrm{E}$ & $18^{\circ} 29^{\prime} 01.2^{\prime \prime} \mathrm{E}$ & $18^{\circ} 19^{\prime} 15.6 ” \mathrm{E}$ & $18^{\circ} 18^{\prime} 28.5 ” \mathrm{E}$ \\
\hline
\end{tabular}


Tab. 3. Final concentrations of applied antibiotics according to EUCAST (EUCAST, 2017).

\begin{tabular}{lccc}
\hline & Coliform bacteria & Enterococci & Coagulase positive staphylococci \\
\cline { 2 - 4 } ATB & 9 & Resistant breakpoint [mg/L] & \\
\hline Ampicillin & 1 & 9 & 3 \\
Ciprofloxacin & 9 & 5 & 9 \\
Chloramphenicol & 5 & - & 2 \\
Gentamicin & $16^{*}$ & 129 & 3 \\
Tetracycline & - & - & 3 \\
Vancomycin & 5 & 5 & 9 \\
\hline
\end{tabular}

*tetracycline concentration according to CLSI resistant breakpoints in case of coliform bacteria (CLSI, 2017).

\section{Detection of antibiotic resistant bacteria}

Samples of surface water $(10 \mathrm{~mL})$ were filtered through a GH Polypro membrane $(0.2 \mu \mathrm{m}$, Pall Corporation, USA) placed on antibiotic and antibiotic free selective diagnostic agar plates. Counts of total coliforms were determined on chromogenic Chromocult coliform agar (Merck, Darmstadt, Germany), enterococci were determined on SlanetzBartley agar (Himedia, India) and coagulase positive staphylococci on Baird-Parker agar (Sigma Aldrich, St. Louis, USA). Antibiotic resistant strains were detected after cultivation on plates containing diagnostic media with different antibiotics. Before counting bacterial forming units, plates with coliform bacteria and coagulase positive staphylococci were incubated for $24 \mathrm{~h}$ at $37{ }^{\circ} \mathrm{C}$ and those with enterococci for $42 \mathrm{~h}$ at $40{ }^{\circ} \mathrm{C}$. Each experiment was ran in triplicate and it was repeated twice. Applied antibiotics (ampicillin, ciprofloxacin, gentamicin, chloramphenicol, tetracycline, and vancomycin) were purchased from Sigma-Aldrich (Germany). Antibiotic resistance was detected according to European Committee on Antimicrobial Susceptibility Testing (EUCAST, 2017) resistance breakpoints summarized in Table 3. Microorganisms that can grow and multiply at this and higher concentrations of antibiotics are considered as resistant. However, EUCAST did not establish resistance breakpoints for tetracycline, which was applied in diagnostic media for resistance testing in concentration established by the Clinical Laboratory Standards Institute for United States (CLSI, 2017). Data were statistically evaluated by the Student's t test.

\section{Results and discussion}

At present, various pollutants are introduced into the environment mainly by anthropogenic activity. Many of these substances end up in wastewater treated in WWTPs. However, many studies have pointed out that current treatment efficiency of WWTP is insufficient and micropolutants end up in surface waters. Moreover, sub-inhibitory concen- trations of pharamceuricals or metals contribute to the spread and development of antimicrobial resistance (Lépesová et al., 2019; Mackulak et al., 2019; Bírošová et al., 2020).

Based on the obvious importance of this issue, surface waters in Slovakia were analyzed focusing on the presence of selected antibiotic resistant bacteria. Surface water samples were taken from various rivers, lakes, dams and one thermal bath in Slovakia. One sample came from a lake in Austria. The samples were taken during the summer season to consider also the exposition of swimmers. Sampling time can greatly affect the detection results. Antibiotic levels in water fluctuate during the year due to increased prescriptions during flu season (February, August), which corresponds with the research of wastewater from WWTPs in Slovakia (Bratislava), when higher concentrations of ciprofloxacin, levofloxacin and norfloxacin were detected in wastewater in February (Birosova et al., 2014).

The number of total coliform bacteria in samples of surface water ranged from 1.74 to $3.69 \log$ CFU/ $10 \mathrm{~mL}$ (Table 4). Escherichia coli was observed in $85 \%$ of samples in lower counts ( 0.3 to $3.1 \log \mathrm{CFU} / 10 \mathrm{~mL}$ ). The highest number of coliform bacteria was observed in sample 2 from river Hron. The highest amount of E. coli was detected in river Hron (sample 22). Enterococci were registered only in 24 samples $(70 \%)$ in the range from 0.78 to $3.81 \log \mathrm{CFU} / 10 \mathrm{~mL}$, the highest number was recorded in river Váh behind WWTP Trenčín (sample 3). Coagulase positive staphylococci were present in $91 \%$ of samples in the range of $0.70-3.03 \log \mathrm{CFU} / 10 \mathrm{~mL}$. Coagulase positive staphylococci were observed in $91 \%$ of samples and ranged from 0.70 to $3.03 \log \mathrm{CFU} / 10 \mathrm{~mL}$ (Table 4). However, some monitored lakes serve as natural swimming pools during recreational season and water should not exceed some microbial indicators of water quality. According to the Slovak Ministry of Health Decree no. 308/2012 Coll. on the requirements for water quality, water quality control and the requirements for operation, equipment of 
Tab. 4. Number of total coliform bacteria (TCB), E. coli (TEC), enterococci (TE) and coagulase positive staphylococci (TCPS) in samples of surface water from rivers, lakes, dams and thermal bath.

\begin{tabular}{|c|c|c|c|c|c|}
\hline \multirow{2}{*}{$\begin{array}{l}\text { Type of } \\
\text { surface } \\
\text { water }\end{array}$} & \multirow{2}{*}{ Sample } & TCB & TEC & TE & TCPS \\
\hline & & \multicolumn{4}{|c|}{$\log$ CFU/10 mL } \\
\hline \multirow{24}{*}{ 先 } & 1 & $2.98 \pm 0.11$ & ND & $2.96 \pm 0.20$ & $3.03 \pm 0.19$ \\
\hline & 2 & $3.69 \pm 0.15$ & $1.90 \pm 0.07$ & $3.00 \pm 0.15$ & $2.23 \pm 0.15$ \\
\hline & 3 & $3.25 \pm 0.13$ & $1.00 \pm 0.10$ & $3.81 \pm 0.24$ & $1.84 \pm 0.15$ \\
\hline & 5 & $2.76 \pm 0.17$ & ND & $1.71 \pm 0.01$ & $1.60 \pm 0.08$ \\
\hline & 6 & $3.41 \pm 0.10$ & $1.70 \pm 0.18$ & $2.65 \pm 0.22$ & $1.70 \pm 0.11$ \\
\hline & 7 & $3.54 \pm 0.21$ & ND & $2.77 \pm 0.18$ & ND \\
\hline & 8 & $2.01 \pm 0.01$ & $2.24 \pm 0.10$ & $2.18 \pm 0.15$ & $2.00 \pm 0.10$ \\
\hline & 9 & $2.87 \pm 0.12$ & $2.43 \pm 0.06$ & $2.68 \pm 0.12$ & $2.50 \pm 0.18$ \\
\hline & 10 & $2.73 \pm 0.15$ & $0.30 \pm 0.02$ & $2.08 \pm 0.12$ & $1.78 \pm 0.12$ \\
\hline & 11 & $2.84 \pm 0.15$ & ND & $2.86 \pm 0.09$ & ND \\
\hline & 12 & $3.52 \pm 0.07$ & $1.84 \pm 0.11$ & $2.88 \pm 0.25$ & $1.63 \pm 0.11$ \\
\hline & 13 & $1.74 \pm 0.01$ & ND & $2.25 \pm 0.13$ & ND \\
\hline & 14 & $2.88 \pm 0.05$ & $1.52 \pm 0.19$ & $2.13 \pm 0.18$ & $1.30 \pm 0.07$ \\
\hline & 21 & $3.16 \pm 0.17$ & $2.96 \pm 0.24$ & $2.00 \pm 0.21$ & $1.93 \pm 0.10$ \\
\hline & 22 & $3.23 \pm 0.12$ & $3.10 \pm 0.23$ & $2.43 \pm 0.16$ & $1.70 \pm 0.15$ \\
\hline & 23 & $2.24 \pm 0.11$ & ND & ND & $2.18 \pm 0.19$ \\
\hline & 24 & $2.83 \pm 0.11$ & $1.40 \pm 0.17$ & ND & $2.64 \pm 0.10$ \\
\hline & 25 & $2.57 \pm 0.10$ & $1.78 \pm 0.06$ & ND & $2.47 \pm 0.12$ \\
\hline & 26 & $2.18 \pm 0.16$ & ND & ND & $1.56 \pm 0.18$ \\
\hline & 28 & $2.72 \pm 0.21$ & $1.70 \pm 0.08$ & $1.00 \pm 0.05$ & $2.06 \pm 0.24$ \\
\hline & 29 & $2.44 \pm 0.19$ & $1.30 \pm 0.10$ & ND & $2.80 \pm 0.20$ \\
\hline & 30 & $2.60 \pm 0.15$ & $1.78 \pm 0.05$ & $0.78 \pm 0.02$ & $2.42 \pm 0.17$ \\
\hline & 31 & $2.72 \pm 0.22$ & $1.48 \pm 0.03$ & ND & $2.27 \pm 0.21$ \\
\hline & 32 & $2.62 \pm 0.10$ & $1.00 \pm 0.11$ & ND & $2.11 \pm 0.26$ \\
\hline \multirow{10}{*}{ 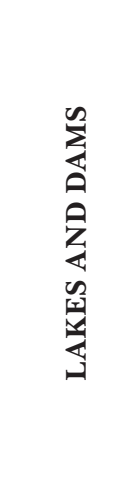 } & 4 & $2.50 \pm 0.28$ & $0.60 \pm 0.08$ & $1.34 \pm 0.12$ & $1.00 \pm 0.01$ \\
\hline & 15 & $2.34 \pm 0.21$ & ND & $1.36 \pm 0.19$ & $1.60 \pm 0.05$ \\
\hline & 16 & $2.45 \pm 0.13$ & $1.30 \pm 0.13$ & $1.38 \pm 0.21$ & $1.70 \pm 0.11$ \\
\hline & 17 & $2.74 \pm 0.10$ & $2.45 \pm 0.22$ & $2.52 \pm 0.26$ & $1.84 \pm 0.15$ \\
\hline & 18 & $2.41 \pm 0.19$ & $1.54 \pm 0.16$ & $1.30 \pm 0.19$ & $1.64 \pm 0.18$ \\
\hline & 19 & $2.70 \pm 0.14$ & $2.60 \pm 0.11$ & $2.24 \pm 0.15$ & $1.34 \pm 0.09$ \\
\hline & 20 & $3.24 \pm 0.29$ & $2.18 \pm 0.18$ & $2.77 \pm 0.11$ & $2.29 \pm 0.07$ \\
\hline & 27 & $2.43 \pm 0.16$ & $1.60 \pm 0.05$ & ND & $1.70 \pm 0.17$ \\
\hline & 33 & $2.97 \pm 0.11$ & ND & ND & $1.60 \pm 0.10$ \\
\hline & 34 & $3.34 \pm 0.10$ & $2.00 \pm 0.09$ & ND & $0.70 \pm 0.18$ \\
\hline
\end{tabular}

$\mathrm{ND}-$ not detected

operating areas, premises and facilities at natural and artificial swimming pools, samples 17, 19 and 20 exceeded limits for E. coli and enterococci.

\section{Occurrence of antibiotic resistant coliform bacteria in surface water}

World Health Organization has established a list of antibiotic resistant priority pathogens for which new antibiotics are urgently needed. The group of critical priority includes also the family of
Enterobacteriaceae resistant to carbapenems, and/ or producing extended spectrum $\beta$-lactamases (Taconelli et al., 2018). Thus, antibiotic resistant coliform bacteria from this family was investigated. Bírošová et al. (2014) and Mackulak et al. (2019) stated that high prevalence of ampicillin resistant coliform bacteria is consistent with frequent prescription of $\beta$-lactams in Slovakia. Fig. 1 shows the comparison of monitored surface water samples. In all cases, ampicillin resistant bacteria were observed 
in the range from $0.6 \log \mathrm{CFU} / 10 \mathrm{~mL}$ in sample 1 (Rudno stream) to $3.01 \log \mathrm{CFU} / 10 \mathrm{~mL}$ in sample 22 (Hron - Kremnička). This finding is not very surprising since, except for E. coli, most coliforms exhibit intrinsic resistance to this antibiotic. In 12 river samples and five lake samples, also tetracycline resistance was determined. Resistance to other tested antibiotics was registered at much lower rate. Seven rivers and one dam contained coliform bac- teria resistant to all applied antibiotics. Antibiotic resistant $E$. coli was determined in 21 samples of surface water (Fig. 2). Ampicillin resistance predominated in all samples and ranged from $0.48 \mathrm{log}$ CFU/10 mL in Orava dam to $2.62 \log$ CFU/10 mL in river Hron (sample 22). Watkinson et al. (2007) determined high incidence of tetracycline resistant E. coli isolated from various sources of surface waters (including those directly affected by WWTP

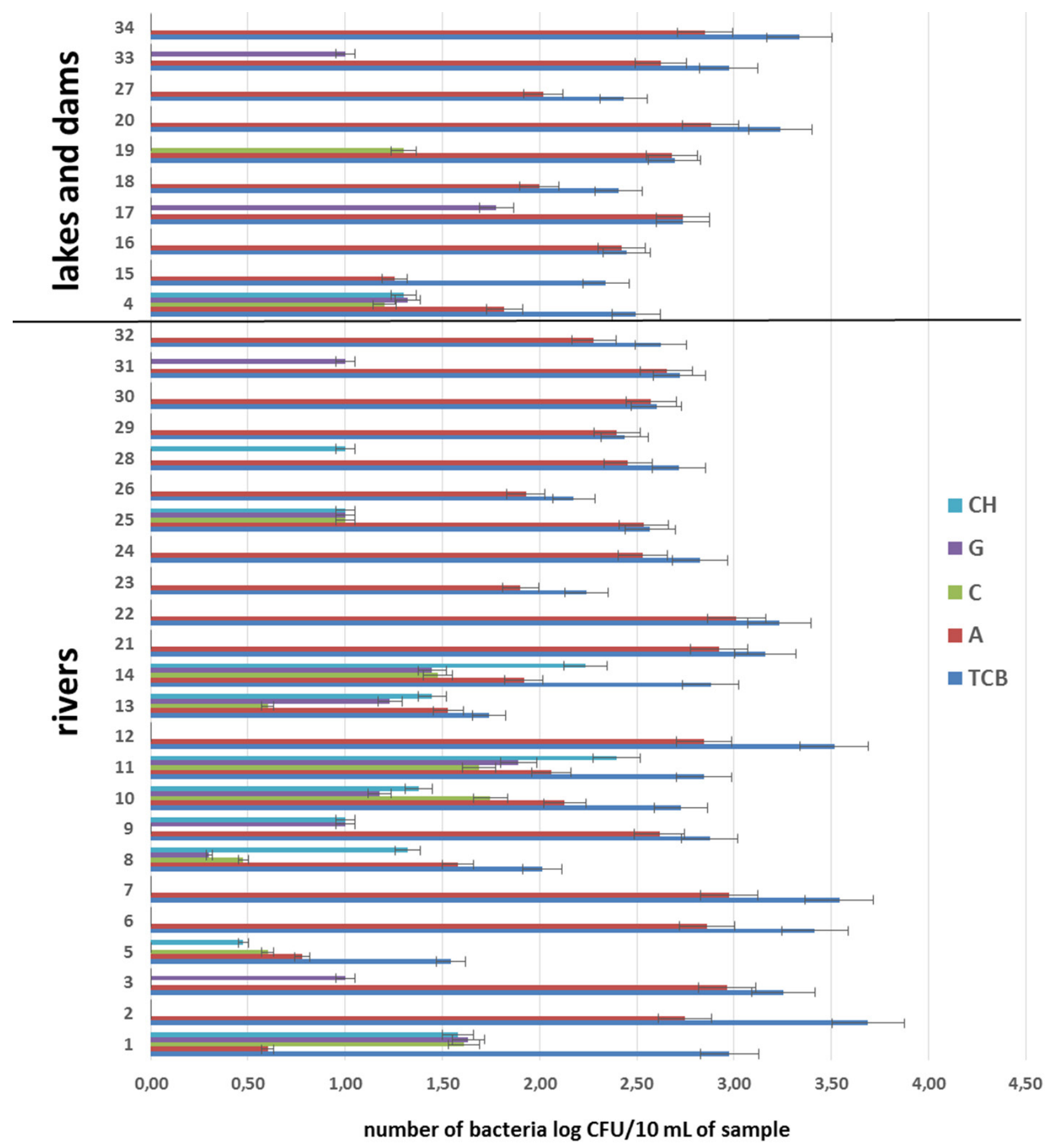

Fig. 1. Number of total and antibiotic resistant coliform bacteria in surface water samples from rivers, lakes, dams and thermal bath (TCB - total coliform bacteria, A - ampicillin resistant coliform bacteria, C - ciprofloxacin resistant coliform bacteria, $\mathrm{G}$ - gentamicin resistant coliform bacteria, $\mathrm{CH}$ - chloramphenicol resistant coliform bacteria). 


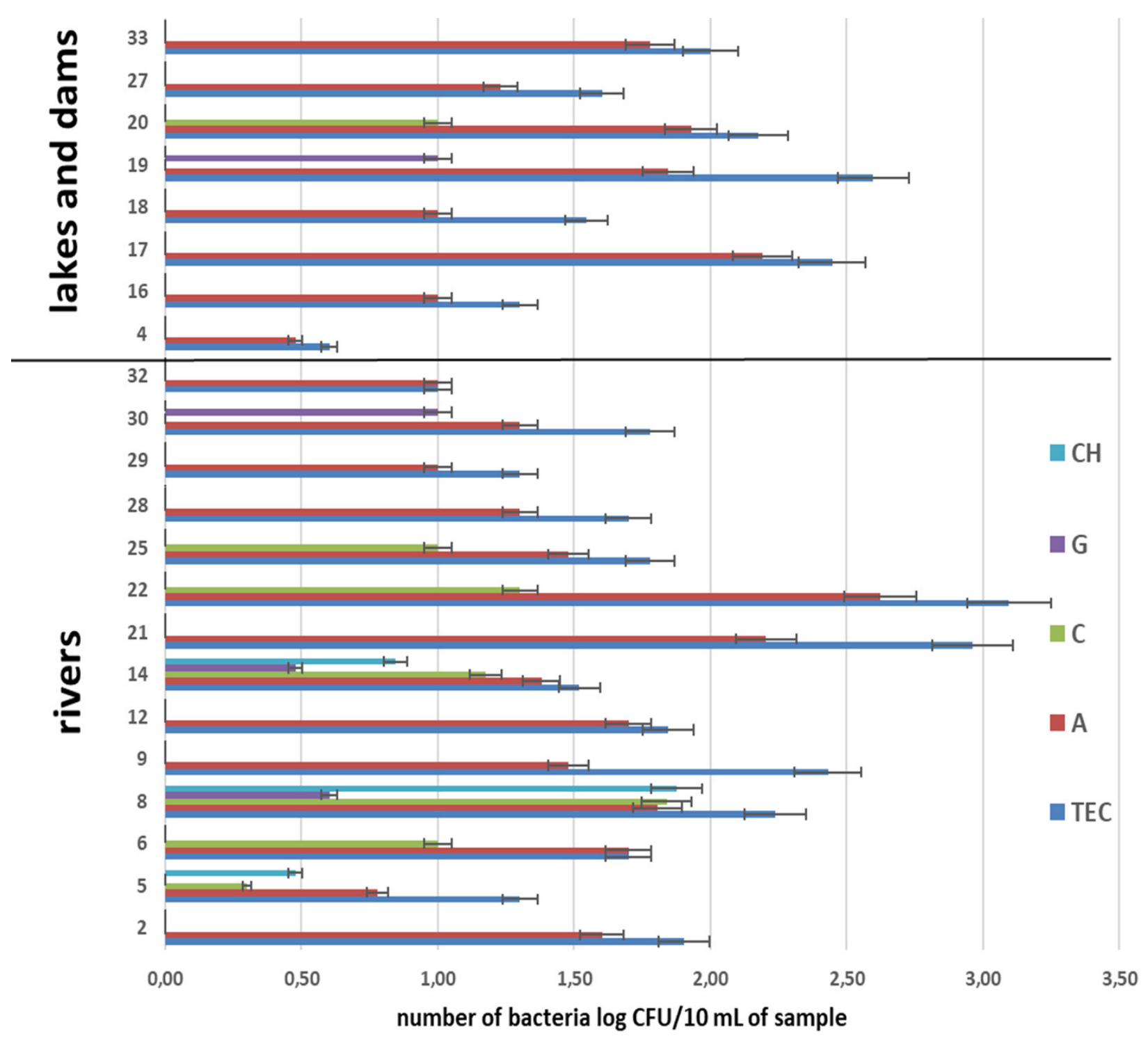

Fig. 2. Number of total and antibiotic resistant E. coli in surface water samples from rivers, lakes, dams and thermal bath (TEG - total E. coli, A - ampicillin resistant E. coli, C - ciprofloxacin resistant E. coli, $\mathrm{G}$ - gentamicin resistant E. coli, CH - chloramphenicol resistant E. coli).

discharges). This partially corresponds with our results; however, tetracycline resistance was also observed predominantly in river samples. River Nitra - Nedožery/Brezany and Danube - Devín, as well as Orava dam contained E. coli resistant to all studied antibiotics.

\section{Occurrence of antibiotic resistant enterococci in surface water}

In recent years, enterococci, belonging to another group of bacteria with significantly increased resistance, are the second most important nosocomial pathogen. This is probably due to the transfer of resistance genes from non-pathogenic enterococci (commonly found within gut microbiota) to pathogenic species. Enterococci, which were initially relatively multidrug resistant, also became vancomycin resistant. The greatest threat is the transmission of vancomycin resistance from enterococci to staphylococci as both strains may occur simultaneously in one patient (Mokrý et al., 2013). Compared to coliform bacteria, much more samples contained enterococci resistant to all applied antibiotics (Fig. 3). In case of lakes (Zlaté piesky, Vajnory lakes, Štrkovec lake) and dam (Orava), this can be due to increased traffic and presence of wild animals (especially birds such doves) which are the source of contamination. All samples contained vancomycin resistant enterococci, which are of high priority in WHO priority pathogen list (Taconelli et al., 2018). This also copies the situation with the prevalence of vancomycin resistant enterococci in hospital effluents and wastewater which finaly gets into rivers and environment (Schwartz et al., 2003; Novais et al., 2005; Mackulak et al., 2019). 


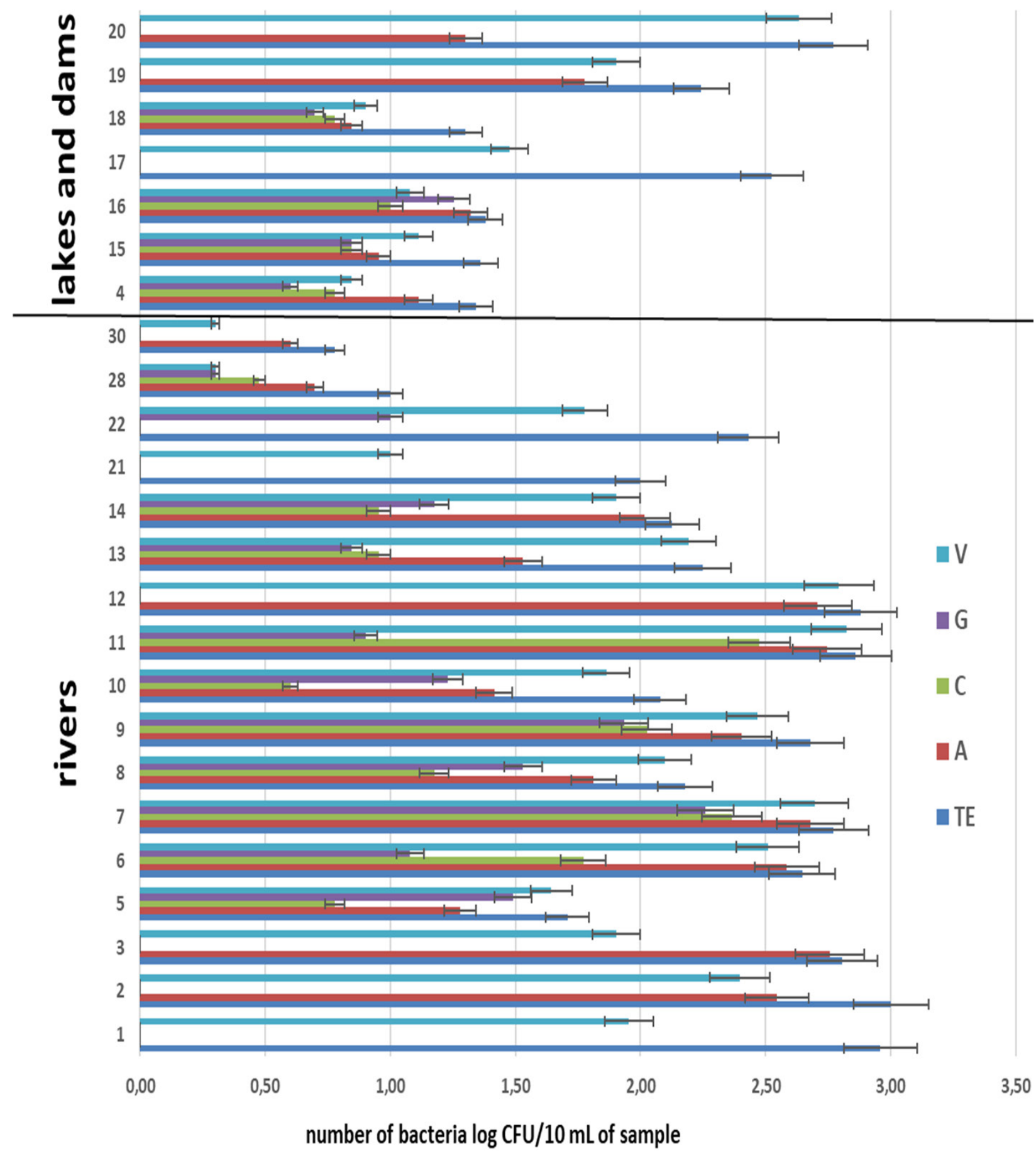

Fig. 3. Number of total and antibiotic resistant enterococci in surface water samples from rivers, lakes, dams and thermal bath (TE - total enterococci, $\mathrm{A}$ - ampicillin resistant enterococci,

$\mathrm{C}$ - ciprofloxacin resistant enterococci, $\mathrm{G}$ - gentamicin resistant enterococci, $\mathrm{V}$ - vancomycin resistant enterococci).

Occurrence of antibiotic resistant coagulase positive staphylococci in surface water

Staphylococci belong to potential pathogens forming common skin microbiota of many people. On the other hand, current emergence of antibiotic resistant strains of staphylococci complicates their treatment. One of the most endangering problem is methicillin resistant Staphylococcus aures which displays multidrug resistance (Yamamoto et al., 2019). Antibiotic resistant staphylococci were observed only in nine samples of surface water (four rivers and five lakes) (Fig. 4). No sample contained coagulase positive staphylococci resistant to all applied antibiotics. The majority of samples (5) contained chloramphenicol resistant strains. However, the use of this antibiotic in Slovakia is delimited and this phenomen is probably caused by cross resistance. Surprisingly, no ciprofloxacin resistance was observed. 


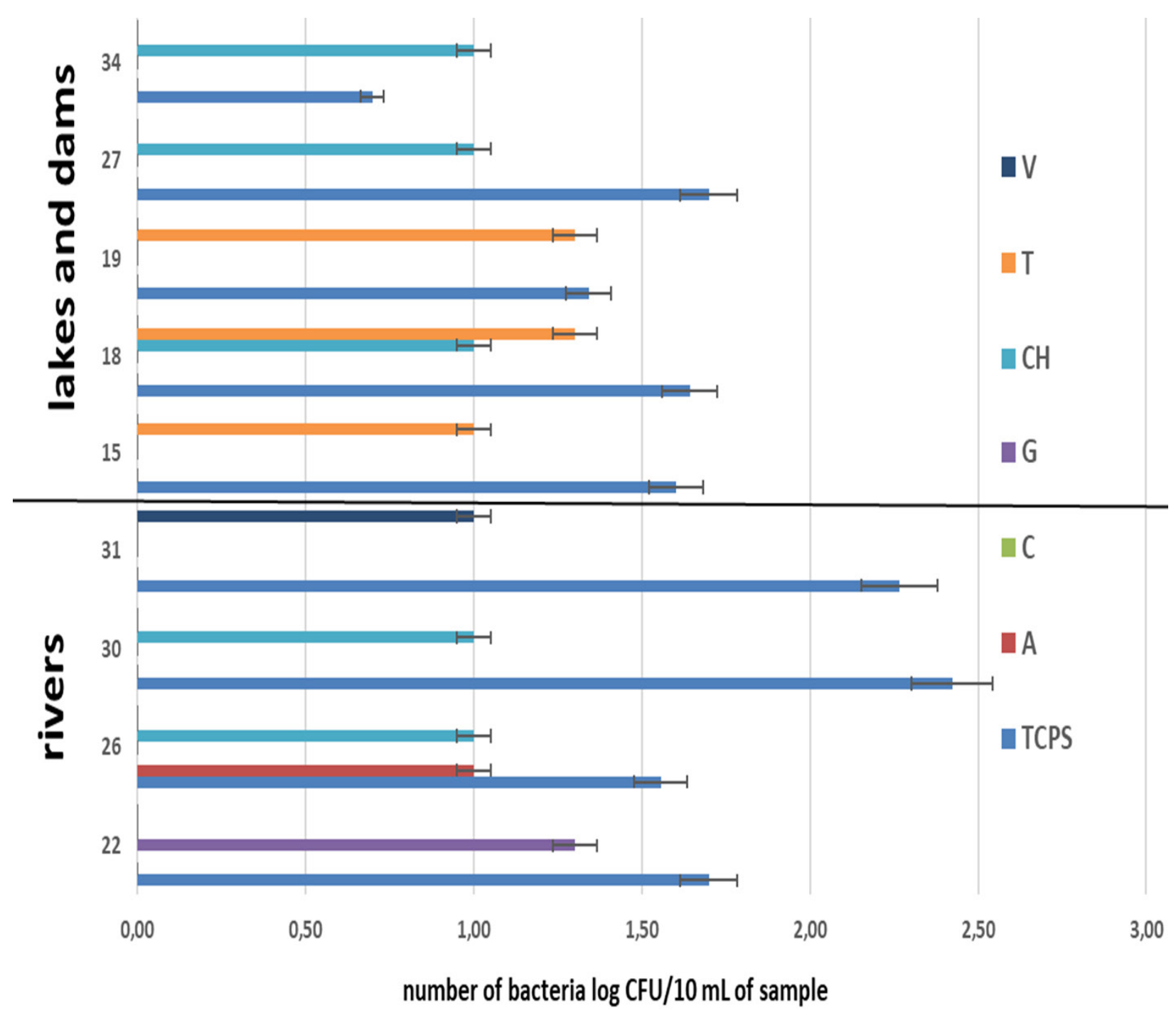

Fig. 4. Number of total and antibiotic resistant coagulase positive staphylococci in surface water samples from rivers, lakes, dams and thermal bath (TCPS - total coagulase positive staphylococci,

A - ampicillin resistant coagulase positive staphylococci, $\mathrm{C}$ - ciprofloxacin resistant coagulase positive staphylococci, G - gentamicin resistant coagulase positive staphylococci, $\mathrm{CH}$ - chloramphenicol resistant coagulase positive staphylococci, $\mathrm{T}$ - tetracycline resistant coagulase positive staphylococci, $\mathrm{V}$ - vancomycin resistant coagulase positive staphylococci).

\section{Conclusion}

Our data show that Slovak surface waters contain different antibiotic resistant bacteria, which can spread resistance genes to other present susceptible microbiota. Some parts of rivers are more microbiologically contaminated, especially near wastewater treatment plants. Our results also point out lakes serving as natural swimming pools during recreational season. In these surface waters, antibiotic resistant bacteria also occur but in lower extent compared to rivers. This contamination is due to higher anthropogenic activity as well as the presence of wild birds, which can contribute to microbiological contamination. During sampling season, three natural swimming pools did not meet limits for water quality given by Decree 308/2012 Coll.

\section{Acknowledgments}

This work was supported by the Slovak Research and Development Agency under the contract No. APVV-160171 and Research grant agency M VEGA grant 1/0096/17.

\section{References}

Aslam B, Wang W, Arshad MI, Khurshid M, Muzammil S, Rasol MH, Nisar MA, Alvi RF, Aslam MA, Qamar MU, Salamat MKF, Baloch Z (2018) Infection and Drug Resistance 11: 1645-1658.

Baquero F, Martínez J-L, Cantón R (2008) Current Opinion in Biotechnology 19(3): 260-265. 
Berendonk U, Manaia CM, Merlin C, Fatta-Kassinos D, Cytryn E, Walsh F, Burgmann H, Sorum H, Norstrom M, Pons M-N, Kreuzinger N, Huovinen P, Stefani S, Schwartz T, Kisand V, Baquero F, Martinez JL (2015) Nature Reviews Microbiology 13 (5): 310-317.

Birošová L, Mackulak T, Bodík I, Ryba J, Škubák J, Grabic R (2014) Science of the Total Environment 490: 440-444.

Bírošová L, Lépesová K, Grabic R, Mackulak T (2020) Environmental Science and Pollution Research (in press).

Clinical Laboratory Standards Institute, CLSI (2017) https://www.sciencedirect.com/science/article/abs/ pii/S1473309917307533

European Committee on Antimicrobial Susceptibility Testing, EUCAST (2017) Breakpoint tables for interpretation of MICs and zone diamteres; Version 7.0 valid from 2017.

Huerta B, Marti E, Gros M, López P, Popeo M, Armengol J, Barceló D, Balcázar JL, Rodriguez-Mozaz S, Marcé R (2013) Science of the Total Environment 456-457: $161-170$.

Lépesová K, Olejníková P, Mackulak T, Tichý J, Birošová L (2019) Environmental Science and Pollution Research 26(18): 18470-18483

Ribeiro AR, Nunes OC, Pereira MFR, Silva AMT (2015) Environment International 75: 33-51.

Mackulak T, Černanský S, Fehér M, Birošová L, Gál M (2019) Current Opinion in Environmental Science and Health 9: 40-48.
Mokrý J, Povrazník I, Váňa J (2013) In: Vybrané kapitoly z klinickej farmakológie, Antimikrobiálne látky I. farmakológia, (pp. 160) Martin: UK, ISBN 978-8089544-48-6.

Niemi M, Sibakov M, Niemela S (1983) Applied and Environmental Microbiology 45 (1): 79-83.

Novais C, Coque TM, Ferreira H, Sousa JC, Peixe L (2005) Applied and Environmental Microbiology 71: 74162.

O'Flaherty E, Cummins E (2017) Human and Ecological Risk Assessment: An International Journal 23(2), 299-322.

Schwartz T, Kohnen W, Jansen B, Obst U (2003) FEMS Microbiology Ecology 43: 325-335.

Stange C, Sidhu JPS, Tiehm A, Toze S (2016) International Journal of Hygiene and Environmental Health 219(8), 823-831.

Stiborová H, Bačáková A, Musilová L, Demnerová K (2018) Chemické listy. 2018, roč. 112: 833-839.

Tacconelli E, Carrara E, Savoldi A, Harbarth S, Mendelson M, Monnet DL, Pulcini C, Kahlmeter G et al. (2018) The Lancet Infectious Diseases 18(3): 318-327.

Watkinson AJ, Micalizzi GB, Graham GM, Bates JB, Costanzo SD (2007) Applied and environmental microbiology 73: 5667-5670.

Yamamoto T, Wan TW, Khokhlova O, Hung WC, Lin YT, Peryanova O, Teng LJ (2019) Medical University 2(4). 